\title{
Chemical composition and pharmacological activities of Pisum sativum
}

\author{
Md Nazmul Hasan Zilani, Tamanna Sultana, S. M. Asabur Rahman, Md Anisuzzman, Md Amirul Islam, \\ Jamil A. Shilpi and Md Golam Hossain
}

\begin{abstract}
Background: Consumption of vegetables has been proven to be effective in the prevention of different diseases. Traditionally edible aerial part of Pisum sativum L. subsp. sativum (Fabaceae) is used to treat diabetes, heart diseases and as blood purifier. Present study was aimed to explore the traditional use of aerial parts of $P$. sativum as a source of antidiabetic agent. In addition, antioxidant activity and chemical composition was carried out.

Methods: Total polyphenol content was spectrophotometrically determined using Folin Chiocalteu's reagent while the flavonoids by aluminum chloride colorimetric assay. Identification of compounds of the extract was made through HPLC and LCMS. Antihyperglycemic activity was assessed by oral glucose tolerance test in mice. Antioxidant activity was determined by DPPH free radical scavenging and reducing power assay.

Results: Total polyphenol and total flavonoids content were found to be $51.23 \mathrm{mg}$ gallic acid equivalent and $30.88 \mathrm{mg}$ quercetin equivalent per gram of dried plant extract respectively. Ellagic acid and $p$-coumeric acid were detected through HPLC. A total of eight compounds including naringenin, $\beta$-sitosterol were indentified through LCMS. In OGT, extract (200 mg/kg bw) showed a 30.24\% decrease $(P<0.05)$ in blood glucose levels at $30 \mathrm{~min}$ compared to the normal control. The extract showed $I C_{50}$ value of $158.52 \mu \mathrm{g} / \mathrm{mL}$ in DPPH scavenging assay and also showed comparable reducing power.

Conclusion: Along with other compounds ellagic acid and $\beta$-sitosterol present in the extract may be responsible for its antioxidant as well as antihyperglycemic activities. Altogether these results rationalize the use of this vegetable in traditional medicine.
\end{abstract}

Keywords: HPLC, LCMS, Ellagic acid, $\beta$-sitosterol, Antioxidant, Antidiabetic

\section{Background}

In hyperglycemia, intracellular carbohydrate metabolism is impaired followed by production of copious number of Reactive Oxygen Species (ROS) by various processes namely glucose oxidation, glucose toxicity and oxidative phosphorylation [1]. In this condition the most devastating ROS engendered in plasma are superoxide anion, hydroxyl and peroxynitrite radicals [2]. Glucose oxidation is believed to be the main source of these free radicals that are responsible for destruction of the pancreatic beta cells responsible for producing insulin [2]. Not only are these radicals involved in the cause of diabetes, they also appear to play a role in some of the complications

\footnotetext{
* Correspondence: mnhzilani09@gmail.com

Pharmacy Discipline, Life Science School, Khulna University, Khulna 9208, Bangladesh
}

(c) The Author(s). 2017 Open Access This article is distributed under the terms of the Creative Commons Attribution 4.0 International License (http://creativecommons.org/licenses/by/4.0/), which permits unrestricted use, distribution, and reproduction in any medium, provided you give appropriate credit to the original author(s) and the source, provide a link to the Creative Commons license, and indicate if changes were made. The Creative Commons Public Domain Dedication waiver (http://creativecommons.org/publicdomain/zero/1.0/) applies to the data made available in this article, unless otherwise stated. antioxidants can be helpful for mopping up these reactive oxygen species. Traditionally natural sources have been used to treat diabetes for a long period of time [3]. About 400 traditional plants including edible herbs have been used to treat diabetes [4]. Antidiabetic activity of edible herb Allium cepa, Allium sativum, Dioscorea dumetorum, Momordica charantia, Coccinia indica, Momordica cymbalaria has been reported $[4,5]$. Edible herbs contain significant bioactive nutritional and health-promoting ingredients with antidiabetic and antioxidant activities [6]. So, herbal plants may be an alternative way of prevention or treatment of diabetes and other fatal diseases caused by reactive species.

P. sativum L. (Fabaceae), locally known as matar, is an annual or perennial herb. It is cultivated throughout the 
Bangladesh [7]. Traditionally seeds are used as nutrient, appetizer, refrigerant, laxative, astringent and also used in treating wrinkled skin, diabetes, acne, phlegm and intestinal inflammation [7, 8]. Antioxidant, antimicrobial and hypoglycemic activities of seeds also have been reported [9]. Furthermore, pericarp of pods showed potential antihyperglycemic activity [10]. Fruits and seeds contain starch, albuminoids, alkaloids, galactolipids, trigonelline, piplartine and essential oils [11]. Petiole and tendril yielded kaempferol-3-triglucoside, quercetin-3triglucoside, and their p-coumaric esters [12, 13]. Newly growth tender (leaves and stem) is used as vegetables in Bangladesh [14]. It is traditionally used in treatment of diabetes, heart diseases and as blood purifier [14].

Literatures reveals that there are very few studies have been reported regarding biological activity or chemical composition of the edible aerial parts of $P$. sativum. As a part of the continuation of our research on bioactivity screening of Bangladeshi medicinal edible herbs, present investigation was carried out to evaluate the usefulness of the P. sativum extract in diabetes by oral glucose tolerance test. It was also tested for antioxidant activity and defined chemically by HPLC and LCMS analysis.

\section{Methods}

\section{Chemicals and reagents}

Gallic acid, caffeic acid, $p$-coumaric acid, $(+)$-catechin hydrate, (-)-epicatechin, vanillic acid, rutin hydrate, ellagicacid, kaempferol, myricetin, quercetin, 2, 2-Diphenyl1-picryldydrazyl (DPPH), ascorbic acid and butylated hydroxy toluene were purchased from Sigma-Aldrich (St. Louis, MO, USA). HPLC grade methanol, acetonitrile, acetic acid and ethanol were obtained from Merck (Darmstadt, Germany). Standard drug Glibenclamide hydrochloride was purchased from Square Pharmaceuticals Ltd., Bangladesh.

\section{Plant materials and extraction}

The edible aerial part of $P$. sativum L. was collected in December 2014 from Khulna, Bangladesh and identified by experts at Bangladesh National Herbarium, Dhaka, Bangladesh. A voucher specimen (DACB 41155) has been submitted there for future reference. The shade dried and grinded powder (500 g) was soaked in $98 \%$ ethanol. After removal of debris and evaporation of solvent by rotary evaporator crude extract (yield $2.8 \% \mathrm{w} / \mathrm{w}$ ) was found and stored at $4{ }^{\circ} \mathrm{C}$ until experiment commenced.

\section{Experimental animals}

In the present study Swiss-albino mice of average weight 22-25 $\mathrm{g}$ and 4-5 weeks age were used. Mice were housed in an ambient room temperature of $24 \pm 1{ }^{\circ} \mathrm{C} ; 12 \mathrm{~h}$ light and dark cycle with controlled humidity. Mice were allowed standard pellet diet and water ad libitum. Ethical guidelines of Organization for Economic Cooperation and Developmentwere followed to carry out the experiment.

\section{Identification of Phytochemical constituents}

To identify the presence of therapeutically active phytochemicals namely flavonoids, polypheols, alkaloids, glycosides, terpenoids, and saponins, standard chemical tests were carried out [15].

\section{Total polyphenol content}

To determine the total polyphenol content of the extract, extract solution $(1 \mathrm{mg} / \mathrm{ml})$ was mixed with $5 \mathrm{~mL}$ of ten times diluted Folin-Ciocalteu reagent. In that mixture, $4 \mathrm{~mL}$ of $75 \mathrm{~g} / \mathrm{L}$ sodium carbonate was added. After incubation period of $30 \mathrm{~min}$ at $40^{\circ} \mathrm{C}$ absorbance of the reaction mixture was measured at $765 \mathrm{~nm}$ using Shimadzu UV visible spectrophotometer (Model 1800, Japan). Gallic acid (0-1 mg/mL) was used to prepare standard calibration curve. Gallic Acid Equivalent (GAE) was determined $(\mathrm{mg} / \mathrm{mL})$ from the equation of calibration line and then total polyphenol content was expressed in terms of $\mathrm{mg}$ of gallic acid equivalent per gram of dry extract [16].

\section{Total flavonoids content}

A well-known aluminum chloride colorimetric method was used to determine the total flavonoids content of the extract [17]. In the extract solution $(1 \mathrm{mg} / \mathrm{ml}), 4 \mathrm{~mL}$ distilled water and $0.3 \mathrm{~mL}$ of $5 \% w / v$ sodium nitrate was sequentially mixed. Five minutes later, $0.3 \mathrm{~mL}$ of $10 \% \mathrm{w} / \mathrm{v}$ aluminum chloride was added to the mixture with continuous shaking. At the sixth minute, $2 \mathrm{~mL}$ of $1 \mathrm{M}$ sodium hydroxide was added and the volume was adjusted to $10 \mathrm{~mL}$. Then absorbance was measured at $510 \mathrm{~nm}$. For this assay quercetin $(0-1 \mathrm{mg} / \mathrm{mL})$ was used for standard calibration curve. After reading the quercetin equivalent from the calibration line, total content of flavonoids was expressed as $\mathrm{mg}$ quercetin equivalent $(\mathrm{QE})$ per gram of dry plant extract.

\section{HPLC detection of polyphenol}

To detect the presence of polyphenols present in the extract, HPLC analysis was carried out on Rapid Separation LC (RSLC) systems (Thermo Fisher Scientific Inc., MA, USA), coupled to separation pump (LPG-3400RS), Ultimate 3000RS autosamplier (WPS-3000) and diode array detector (DAD-3000RS). Separation was carried out at $30{ }^{\circ} \mathrm{C}$ using Acclaim ${ }^{\circ} \mathrm{C} 18(4.6 \times 250 \mathrm{~mm} ; 5 \mu \mathrm{m})$ column (Dionix, USA) and injection volume of $20 \mu \mathrm{l}$. Gradient method was applied as 5\%A/95\%B, 0 min; 10\%A/ $80 \% \mathrm{~B} / 10 \% \mathrm{C}, 10 \mathrm{~min} ; 20 \% \mathrm{~A} / 60 \% \mathrm{~B} / 20 \% \mathrm{C}, 20 \mathrm{~min}$ and $100 \% \mathrm{~A}$ at $30 \mathrm{~min}$ and $5 \mathrm{~min}$ post run with solvent $\mathrm{A}$. For spectrophotometric detection, the wavelength was 
optimized at $280 \mathrm{~nm}$ for first eighteen min, $320 \mathrm{~nm}$ for next six minand finally to $380 \mathrm{~nm}$ for the rest of the analysis and the diode array detector was set at a range from 200 to $70 \mathrm{~nm}$. Acetonitrile (solvent A), acetic acid solution $\mathrm{pH} 3.0$ (solvent $\mathrm{B}$ ), and methanol (solvent C) were used as mobile phase with flow rate at $1 \mathrm{~mL} / \mathrm{min}$.

For the calibration curve, gallic acid, (+)-catechin hydrate, vanillic acid, (-)-epicatechin, $p$-coumaric acid, ellagic acid, myricetin, kaempferol (1.0-5.0 $\mu \mathrm{g} / \mathrm{mL}) ;(+)-$ catechin hydrate, caffeic acid, rutin hydrate $(0.5-4.0 \mu \mathrm{g} /$ $\mathrm{mL})$ and quercetin $(0.25-3.0 \mu \mathrm{g} / \mathrm{mL})$ were used as standard. Extracts solution $(5.0 \mathrm{mg} / \mathrm{mL})$ were prepared in ethanol by vortex mixing for $30 \mathrm{~min}$. Prior to HPLC analysis mixed standards, sample and spiked solutions were filtered through $0.20 \mu \mathrm{m}$ nylon syringe filter and degassed in an ultrasonic bath for $15 \mathrm{~min}$ [18].

\section{Chemical profiling through LCMS}

Liquid Chromatography Mass Spectroscopy (LCMS) analysis was performed using Agilent 6530 Accurate-Mass QTOF LC-MS system. It equipped with a reversed-phase C18 analytical column of $50 \mathrm{~mm} \times 2.1 \mathrm{~mm} \times 1.8 \mu \mathrm{m}$ particle size (Agilent 6530). The column oven temperature was set at $35{ }^{\circ} \mathrm{C}$, and the flow rate was $250 \mu \mathrm{L} / \mathrm{min}$. Mobile phases $\mathrm{A}$ and $\mathrm{B}$ were water and acetonitrile, respectively, each containing $5 \mathrm{mM}$ ammonium formate and $0.1 \%$ formic acid. The linear gradient programme was set as follows: $0 \mathrm{~min}, 100 \% \mathrm{~A} ; 45 \mathrm{~min}, 100 \% \mathrm{~B} ; 50 \mathrm{~min}$, $100 \% \mathrm{~B} ; 55 \mathrm{~min}, 100 \% \mathrm{~A}$. The injection volume was $20 \mu \mathrm{L}$ with a run time of $15 \mathrm{~min}$. The UHPLC was hyphenated to a triple quadrupole mass spectrometer 3200 QTrap (ABSciex) equipped with an electrospray ionization interface set at negative mode. The interface heater held at the temperature of $500{ }^{\circ} \mathrm{C}$ and an ion-spray (IS) voltage of $-4500 \mathrm{eV}$. The nebulising gas (GS1), heating gas (GS2) and curtain gas pressures set at 40, 40 and $10 \mathrm{psi}$, respectively during the whole analysis. Nitrogen was used as collision and spray gas. Full scan data acquisition was performed, scanning from $\mathrm{m} / \mathrm{z} 5$ to 1500 in enhanced MS IDA EPI mode [19].

\section{Oral glucose tolerance test}

Oral glucose tolerance was assessed using overnight $(16 \mathrm{~h})$ fasted mice. It was divided into four groups containing five mice in each group. Group I was treated as control and group II received standard glibenclamide $(5 \mathrm{mg} / \mathrm{kg}$, orally). Group III and IV were orally treated with extract of 100 and $200 \mathrm{mg} / \mathrm{kg}$ body weight respectively. Glucose $(3 \mathrm{~g} / \mathrm{kg})$ was administered orally after $30 \mathrm{~min}$ of oral administration of extract. Blood samples were collected from tail vein at $0,30,60,90$ and 120 mins after glucose load. The blood glucose levels were analyzed using glucose test strips and glucose meter (EZ Smart-168, Tyson Bioresearch Inc., Taiwan) [17].

\section{Acute toxicity test}

Acute oral toxicity of the extract was assessed in mice according to the guidelines of the Organization for Economic Cooperation and Development [17]. The mice were fasted overnight $(16 \mathrm{~h})$, divided into 5 groups $(n=5)$ and the extract was orally administered at the dose of 100, 200,400 and $800 \mathrm{mg} / \mathrm{kg}$ body weight. The control group received distilled water. Individual observations for lethality and any physical sign of toxicity of mice were started during the first two hours continuously and then at six hours interval for $24 \mathrm{~h}$ time period and finally after every $24 \mathrm{~h}$ up to 14 days.

\section{DPPH free radical scavenging assay}

A stock solution of $1024 \mu \mathrm{g} / \mathrm{mLwas}$ prepared to determine the DPPH radical scavenging activity of the extract. Different concentrations $(512,256,128,64,32,16,8,4$, 2, $1 \mu \mathrm{g} / \mathrm{mL}$ ) were obtained through serial dilution of stock solution. In $3 \mathrm{~mL}$ of freshly prepared $0.004 \% \mathrm{w} / v$ DPPH solution, $1 \mathrm{~mL}$ sample solution was added. After incubation of $30 \mathrm{~min}$ at dark place, absorbance of each concentration was measured at $517 \mathrm{~nm}$. Ascorbic acid was used as standard free radical scavenger. The scavenging activity of the samples was calculated using the formula: \% scavenging activity $=\left[\left(\mathrm{Abs}_{\mathrm{c}}-\mathrm{Abs}_{\mathrm{s}}\right) / \mathrm{Abs}_{\mathrm{c}}\right] \times 100$; where $\mathrm{Abs}_{\mathrm{c}}$ is the absorbance of control and $\mathrm{Abs}_{\mathrm{s}}$ is the absorbance of extract or standard. Concentration required to scavenge $50 \%$ of free $\mathrm{DPPH}\left(\mathrm{IC}_{50}\right.$ value) was estimated from the obtained data [18].

\section{Reducing power assay}

To determine the reducing power of the extract, from the stock solution different concentrations $(0.1-1 \mathrm{mg} /$ $\mathrm{mL}$ ) of extract was prepared. $\mathrm{In} 1 \mathrm{~mL}$ of sample solution, $0.2 \mathrm{M}$ phosphate buffer $(2.5 \mathrm{~mL} ; \mathrm{pH} 6.6)$ and $10 \mathrm{~g} / \mathrm{L}$ potassium ferricyanide $(2.5 \mathrm{~mL})$ were added. The mixture was incubated at $50^{\circ} \mathrm{C}$ for $20 \mathrm{~min}$. After cooling at room temperature, $100 \mathrm{~g} / \mathrm{L}$ trichloroacetic acid $(2.5 \mathrm{~mL})$ was added. The mixture was centrifuged at $3000 \mathrm{rpm}$. For $10 \mathrm{~min}$. In the supernatant $(2.5 \mathrm{~mL})$, distilled water $(2.5 \mathrm{~mL})$ and $1 \mathrm{~g} / \mathrm{L}$ ferric chloride $(0.50 \mathrm{~mL})$ were added. After 10mins, absorbance of the mixture was measured at $700 \mathrm{~nm}$. Butylated Hydroxy Toluene (BHT) was used as standard [20].

\section{Statistical analyses}

Data acquisition, peak integration and calibrations in HPLC were performed with DionixChromeleon software (Version 6.80 RS 10). Analyst software version 1.5.2 was used for method development, data acquisition and data processing in LCMS. Statistical significance of oral glucose tolerance test was estimated by student's $t$-test. All values were expressed as mean $\pm \mathrm{SD}$ of three parallel measurements. 


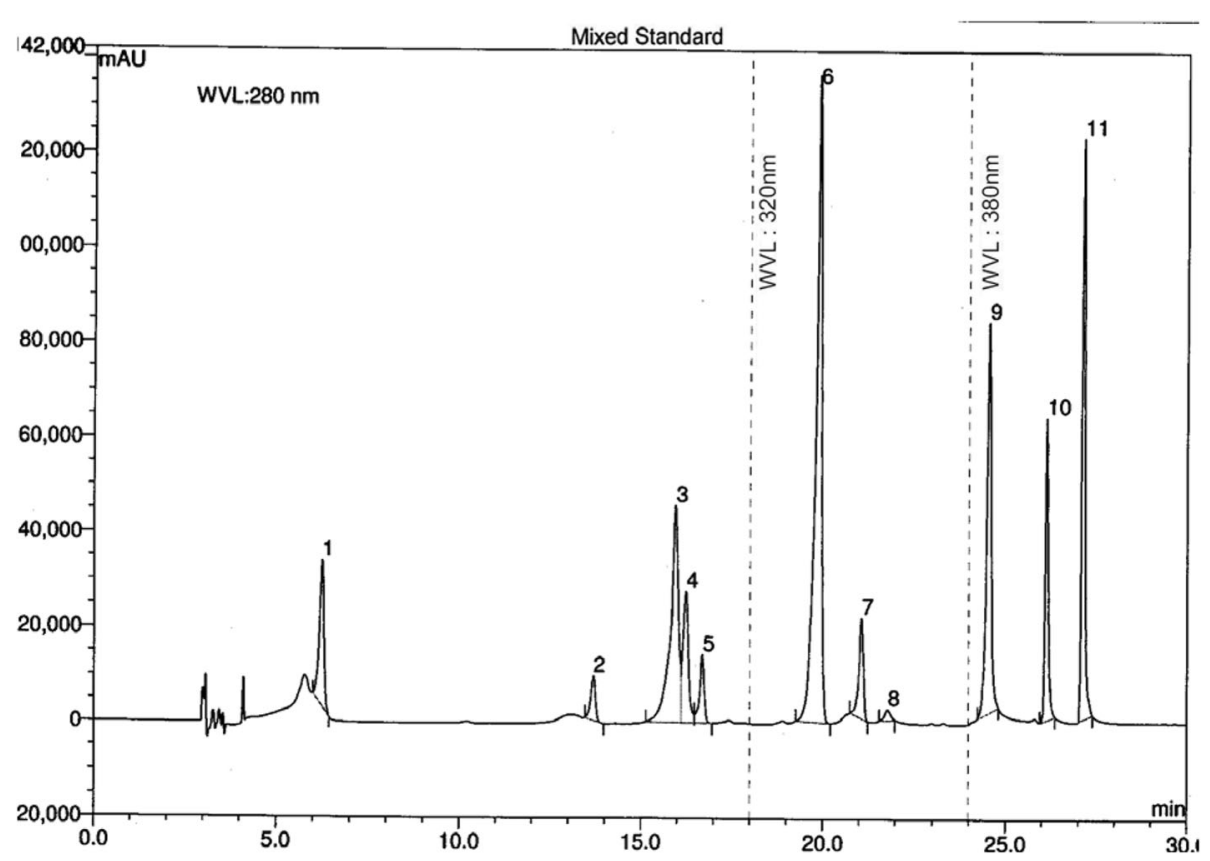

Fig. $1 \mathrm{HPLC}$ chromatogram of a standard mixture of polyphenolic compounds (peak 1: gallicacid, 2:(+)-catechin, 3:vanillic acid 4: caffeic acid 5: (-)-epicatechin 6: $p$-coumaric acid 7: rutin hydrate 8: ellagic acid 9: myricetin, 10: quercetin, 11: kaempferol)

\section{Results}

In the preliminary phytochemical screening, the extract showed the presence of therapeutically active phytochemicals flavonoids, polyphenols, alkaloids, glycosides, terpenoid and absence of saponins. To determine total phenol content acalibration curve was prepared from graph of concentration versus absorbance of standard gallic acid. The equation $\mathrm{y}=8.043+0.213, \mathrm{R}^{2}=0.985$ was obtained from that curve. Total phenolic content of the extract was calculated and found to be $51.23 \mathrm{mg}$ gallic acid equivalent per gram of dry extract. Quercetin as standard was used to obtain a calibration curve with the equation $y=1.169+0.008, R^{2}=0.994$ from which total flavonoid content of the extract was calculated as

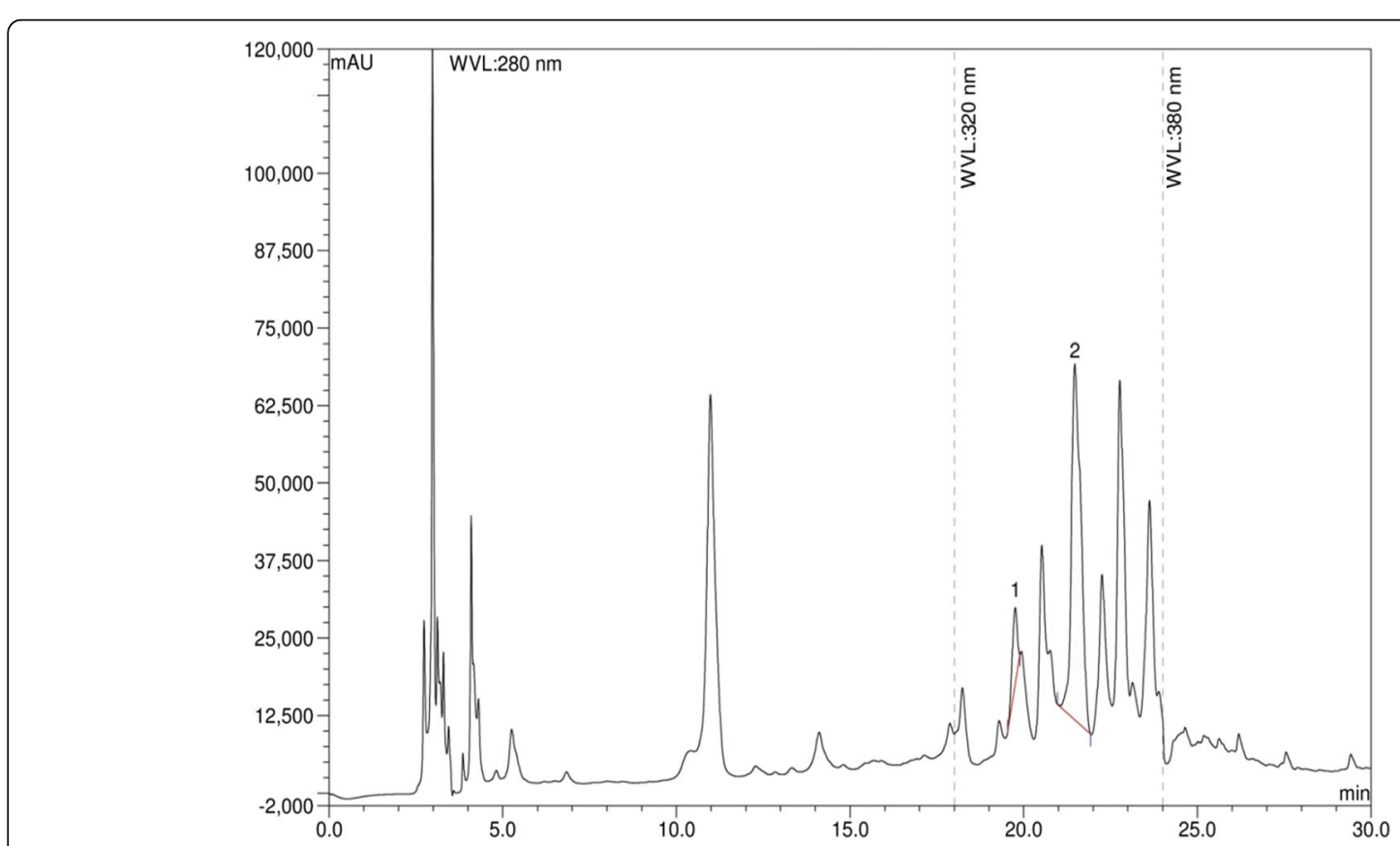

Fig. 2 HPLC chromatogram of ethanol extract of $P$. sativum (peak 1: p-coumaric acid, 2: ellagic acid) 
Table 1 Contents of polyphenolic compounds in P. sativum extract

\begin{tabular}{lll}
\hline Polyphenolic Compound & Content $(\mathrm{mg} / 100 \mathrm{~g}$ of dry extract) & $\% \mathrm{RSD}^{\mathrm{a}}$ \\
\hline$p$-Coumaric acid & 7.78 & 0.19 \\
Ellagic acid & 899.19 & 6.83
\end{tabular}

${ }^{a}$ RSD Relative Standard Deviation

$30.88 \mathrm{mg} \mathrm{QEg}^{-1}$ dry extract. In HPLC analysis of polyphenols, eleven standard polyphenol compounds were used for comparison. Among these compounds extractcontained a very high concentration of ellagic acid (899.19 mg per $100 \mathrm{~g}$ of dry weight) and fairly low (7.78 mg per $100 \mathrm{~g}$ of dry weight) amount of $p$-coumaric acid. The chromatographic profiles of standard polyphenol compounds and extract were presented in Figs. 1 and 2. The concentrations of present phenolic compounds were calculated based on the calibration curves of the standards and reported in Table 1. The LCMS base peak chromatogram of the ethanol extract was shown in Fig. 3. From LCMS data and the related literatures $\beta$ sitosterol, $\beta$-amyrin, kaempferol-3-neohesperidoside, 6prenylpinocembrin, naringenin, kaempferol-3- glucoside, 1,2-benzenedicarboxylic acid, 6H-Benzofuro[3,2-c][1] benzopyran and diisooctyl esterwere identified in the extract. The chromatographic and LCMS data including retention time, experimental and calculated $\mathrm{M}+\mathrm{H}$, molecular formulas and proposed compounds were summarized in Table 2.
The antihyperglycemic effects of the $P$. sativum extract on the oral glucose tolerance test (OGTT) in nondiabetic micewere presented in Table 3. The maximum plasma glucosein the normal control group was at $30 \mathrm{~min}$ after glucose $(3 \mathrm{~g} / \mathrm{kg})$ loading and then gradually declined. The treatment with different doses of extract $(100$ and $200 \mathrm{mg} / \mathrm{kg})$ significantly $(P<0.05)$ reduced blood glucose levels by $18.15 \%, 30.24 \%$ at $30 \mathrm{~min}$ respectively, and significant $(P<0.05)$ reduction in the following hours was observed only at $200 \mathrm{mg} / \mathrm{kg}$ treated mice (Table 3 and Fig. 4). Mice treated with oral antidiabetic reference drug glibenclamide showed significant $(P<$ 0.05 ) reduction in blood glucose levels at $30,60,90$, and 120 min after glucose load compared to normalcontrol (Table 3 and Fig. 4). The oral acute toxicity evaluation of the extract at 100, 200, 400 and $800 \mathrm{mg} / \mathrm{kg}$ body weight resulted in no mortality and no visible signs of acutetoxicity throughout the 14 days. These results indicated that the $\mathrm{LD}_{50}$ (lethal dose in $50 \%$ ) value of the extract was greater than $800 \mathrm{mg} / \mathrm{kg}$ body weight.

The DPPH radical scavenging activity of the extract $\left(\mathrm{IC}_{50}=158.52 \pm 5.46 \mu \mathrm{g} / \mathrm{mL}\right)$ was approximately ten fold lesser than that of the standard ascorbic acid $\left(\mathrm{IC}_{50}=14.70 \pm 3.24 \mu \mathrm{g} / \mathrm{mL}\right)$. A concentration dependent reducing capacity of the extract was found. At the concentrations of $0.1,0.2,0.3,0.4,0.5$ and $1 \mathrm{mg} / \mathrm{mL}$ extract showed absorbance of $0.092,0.123$,

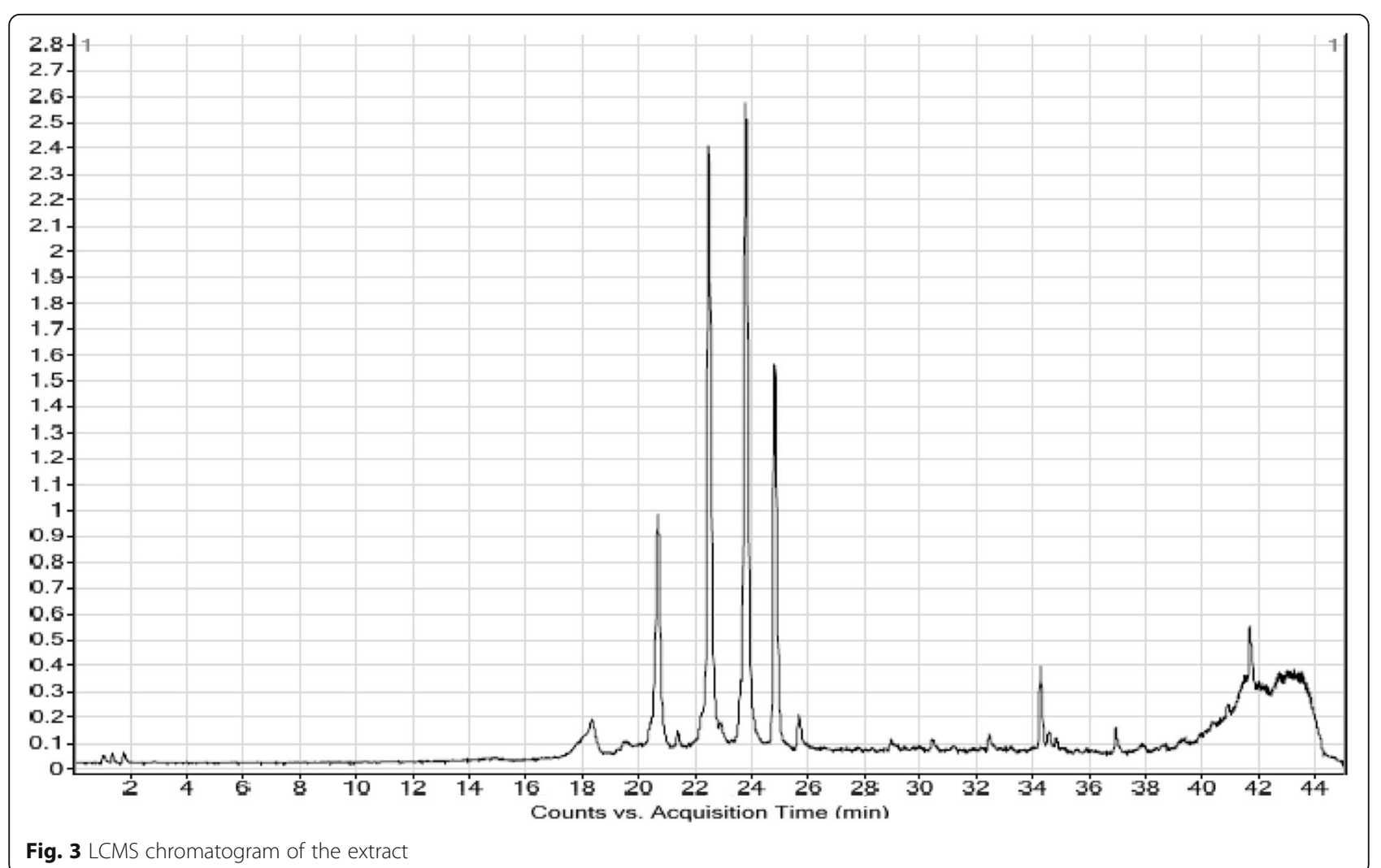

Fig. 3 LCMS chromatogram of the extract 
Table $\mathbf{2}$ LCMS data of the compounds identified in the extract

\begin{tabular}{llllll}
\hline RT (min) & $\mathrm{M}+\mathrm{H}$ experimental & Molecular formula & $\mathrm{M}+\mathrm{H}$ calculated & Suggested compound & Reference \\
\hline 1.013 & 427.0791 & $\mathrm{C}_{30} \mathrm{H}_{50} \mathrm{O}$ & 426.386 & $\beta$-amyrin & [42] \\
20.403 & 285.1232 & $\mathrm{C}_{17} \mathrm{H}_{16} \mathrm{O}_{4}$ & 284.30 & 6H-Benzofuro[3,2-c][1]benzopyran & [43] \\
21.279 & 415.2408 & $\mathrm{C}_{29} \mathrm{H}_{50} \mathrm{O}$ & 414.71 & B-sitosterol & [44] \\
22.959 & 391.28 & $\mathrm{C}_{24} \mathrm{H}_{38} \mathrm{O}_{4}$ & 390.55 & 1,2-Benzenedicarboxylic acid, diisooctyl ester & [45] \\
23.680 & 595.45 & $\mathrm{C}_{27} \mathrm{H}_{30} \mathrm{O}_{15}$ & 594.51 & kaempferol-3-neohesperidoside & [46] \\
34.316 & 325.22 & $\mathrm{C}_{20} \mathrm{H}_{20} \mathrm{O}_{4}$ & 324.3704 & 6-prenylpinocembrin & [47] \\
36.622 & 273.18 & $\mathrm{C}_{15} \mathrm{H}_{12} \mathrm{O}_{5}$ & 272.25278 & Naringenin & [48] \\
40.302 & 449.3385 & $\mathrm{C}_{21} \mathrm{H}_{20} \mathrm{O}_{11}$ & 448.38 & Kaempferol-3-glucoside & [46] \\
\hline
\end{tabular}

$0.205,0.216,0.239$, and 0.544 while standard butylated hydroxytoluene showed absorbance of 0.467, 0.733, $1.059,1.107,1.242$, and 1.472 , respectively.

\section{Discussion}

Medicinal plants are traditionally used for therapeutic purposes. Secondary metabolites of plants are mainly responsible for therapeutic action in biological system [21]. Biological actions depend on the concentration of secondary metabolites in plant cells that fluctuate along with seasons, climates, particular growth phases, plant parts and extracting solvent [22]. Leaves are one of the highest sources of bioactive compounds [22]. Some studies have suggested that consumption of commonly used vegetables has been proven to reduce the risk of life threatening diseases as vegetables have appeared for noteworthy sources of bioactive compounds [23].

Oxidative stress is one of the major causes of reduced glucose tolerance [24]. Antioxidant compounds with antihyperglycemic activities may be the best way to ameliorate the condition. The relation of antioxidant and glucose tolerance capacity of several compounds has been reported earlier [25]. The treatment with different doses of extract $(100$ and $200 \mathrm{mg} / \mathrm{kg})$ significantly $(P<$ 0.05 ) reduced blood glucose levels by $18.15 \%, 30.24 \%$ at 30min respectively, and significant $(P<0.05)$ reduction in the following hours was only observed at $200 \mathrm{mg} / \mathrm{kg}$ treated mice. Antihyperglycemic activity of the extract is comparable to the previous studies $[10,26]$. The in vivo anti-diabetic activity of plant extracts has been correlated with their flavonoid and total phenolic content
[27]. The presence of secondary metabolites such as alkaloids, polyphenols, flavonoid, glycosides, tannins and terpenoid in the ethanol extract of $P$. sativum may contribute to its antihyperglycemic activity and other medicinal values. Also, the extract contains significant amount of polyphenol and flavonoid content that is slightly higher in comparison to reported studies [10, 28, 29]. Different bioactive compounds of flavonoids, polyphenols, glycosides and terpenoids have been identified in the extract. $\beta$-sitosterol, identified in the extract has potential antidiabetic effect. It stimulates basal glucose uptake, the primary requisite for maintaining glucose homeostasis, through LKB1 (Liver Kinase B1) mediated AMP-activated protein kinase (AMPK) activation and also possesses insulin-like properties [30, 31]. On the other hands, polyphenolic ellagic acid potentiates pancreatic secretion, increases glucose uptake, liver and muscle glycogen content, decreases glucose intolerance and reduces glucose absorption by inhibiting glucosidase enzyme [32, 33]. The flavonoid, kaempferol improves insulin-stimulated glucose uptake in mature adipocytes [34] and naringenin suppresses carbohydrate absorption from intestine, exerts extra-pancreatic action [35]. One of the isolated compounds, $\beta$-amyrin improves glycemia possibly by its interaction with cannabinoid system [36]. These may be the possible mechanisms underlying the anti-diabetic activity of the extract.

The antioxidant potential of plant extract depends on the chosen method, concentration and physicochemical properties of components present in the extract. Vegetable as dietary sources contains significant amount of

Table 3 Effect of extract on mice during oral glucose tolerance test

\begin{tabular}{|c|c|c|c|c|c|}
\hline \multirow[t]{2}{*}{ Treatment } & \multirow[b]{2}{*}{$0 \mathrm{~min}$} & \multicolumn{4}{|c|}{ Blood glucose level ${ }^{a}(\mathrm{mmol} / \mathrm{L})$} \\
\hline & & $30 \min$ & $60 \mathrm{~min}$ & $90 \min$ & $120 \min$ \\
\hline Control (10 mL/kg) & $5.28 \pm 1.42$ & $12.40 \pm 3.16$ & $10.92 \pm 2.56$ & $7.95 \pm 0.59$ & $6.8 \pm 0.08$ \\
\hline Glibenclamide (5 mg/kg) & $5.06 \pm 1.32$ & $7.54 \pm 3.62^{*}$ & $6.97 \pm 2.63^{*}$ & $5.54 \pm 1.28^{*}$ & $5.3 \pm 0.95^{*}$ \\
\hline Extract $(100$ mg/kg) & $5.16 \pm 2.11$ & $10.15 \pm 2.76^{*}$ & $9.28 \pm 3.12^{*}$ & $7.2 \pm 2.63$ & $6.7 \pm 3.24$ \\
\hline Extract $(200$ mg/kg) & $4.94 \pm 2.11$ & $8.65 \pm 3.28^{*}$ & $8.05 \pm 2.54^{*}$ & $6.5 \pm 2.29^{*}$ & $5.9 \pm 2.34^{*}$ \\
\hline
\end{tabular}

a Values represent as mean $\pm \mathrm{SD}, n=5,{ }^{*} P<0.05$ vs. control, Student's $t$-test 


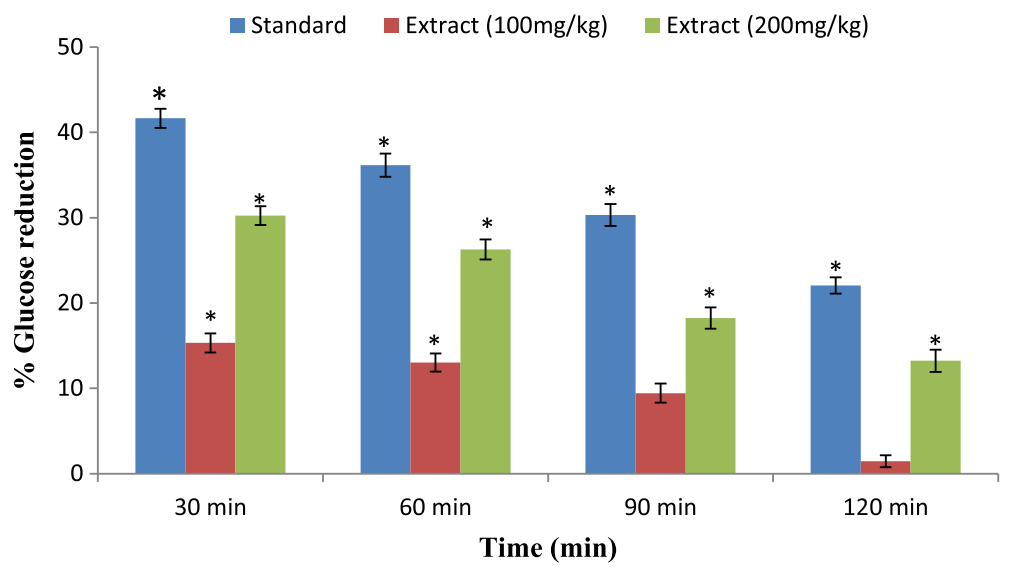

Fig. 4 Percent reduction of blood sugar content by the different doses of extract

polyphenols that are responsible for multiple biological responses including antioxidant activity $[37,38]$. In the present investigation extract showed dose dependent $\mathrm{DPPH}$ radical scavenging activity with the $\mathrm{IC}_{50}$ value of $158.52 \mu \mathrm{g} / \mathrm{mL}$. Also in reducing power assay the extract showed moderate in action as free radical chain breaking agent. These results are comparable to that of previous studies $[10,28,29]$. Antioxidant activity of polyphenol identified in the extract namely ellagic acid, p-coumaric acid, naringenin, kaempferol has been reported $[39,40]$. Also $\beta$-sitosterol has potential antioxidant effect [41]. These compounds act as hydrogen atom donor and neutralize DPPH • to DPPH-H and also break free radical induced chain reactions. All these identified compounds in the extract may be responsible for its antioxidant activity.

A number of studies have been reported the correlation of free radicals, antioxidants and protection of cellular essential components of insulin secretion and glucose uptake mechanism. Antioxidants may regulate insulin secretion, glucose uptake and consequent antihyperglycemic activity by several pathways namely up regulation of hepatic and adipocyte PPAR and GLUT4; phosphorylation of AMPK; activation of PPAR targetgenes; modulation of SREBP-1c; enhancement of antiapoptotic AKT (also known as protein kinase B (PKB)) and $\mathrm{Bcl}-2$ proteins, enhanced cAMP signaling and phosphatidylinositol-4,5-bisphosphate 3-kinase (PI3K).

\section{Conclusion}

In the present study, we have evaluated the antihyperglycemic and antioxidant activities of the ethanol extract of $P$. sativum. The extract showed potentantihyperglycemic effect in oral glucose tolerance test in mice. The extract also demonstrated antioxidant effect. The presence of biologically active compounds ellagic acid and $\beta$-sitosterol could justify the results obtained.
Our study also correlated to the chemical profile and traditional uses of the experimental edible herb that supported the traditional use of $P$. sativum as a promising natural pharmaceutical for combating diabetes.

\section{Abbreviations}

AMPK: AMP-activated protein kinase; BHT: Butylated Hydroxy Toluene; DPPH: 2,2-diphenyl-1-picryldydrazyl; GAE: Gallic Acid Equivalent; HPLC: High Performance Liquid Chromatography; $\mathrm{IC}_{50}$ : 50\% Inhibitory Concentration; LCMS: Liquid Chromatography Mass Spectroscopy; LD 50 : Lethal dose in 50\% test animal; LKB1: Liver Kinase B1; QE: Quercetin Equivalent; $R^{2}$ : Coefficient of Determination; ROS: Reactive Oxygen Species; RSD: Relative Standard Deviation

\section{Acknowledgments}

Authors are grateful to Pharmacy Discipline, Life Science School, Khulna University, Bangladesh for providing technical support. We would like thanks Mr. Hemayet Hossain, Scientific Officer, BCSIR, Dhaka, Bangladesh for helping HPLC analysis of the sample.

Availability of data and materials

The datasets supporting the conclusions of this article are included within the article.

\section{Authors' contributions}

This work has been carried out in collaboration among authors. MNHZ, TS, MA have performed the extraction, antioxidant, antihyperglycemic studies and HPLC analysis. MNHZ and JAS have done LCMS profiling. MAI carried out the statistical analysis. SMAR havemanaged the literature searches and performed phytochemical screening. MAI, JAS and GH designed the study and drafted the manuscript. All authors read and approved the final manuscript.

\section{Competing interests}

The authors declare that they have no competing interests.

\section{Consent for publication}

Not applicable.

\section{Ethics approval}

In our study, Organization for Economic Cooperation and Development guidelines for the care and use of animals were followed. Our study was approved by a research Ethics Committee for Animal House of Pharmacy Discipline, Life Science School, Khulna University, Khulna-9208, Bangladesh. Three members ethics committee consists of Dr. Ashis Kumar Das, Professor and chairman of the committee (dasasish03@yahoo.com), Dr. Jamil Ahmad Shilpi (jamilshilpi@yahoo.com), Professor and Dr. Sheikh Jamal Uddin, Associate Professor (uddinsj@yahoo.com); Pharmacy Discipline, Life Science School, Khulna University, Khulna-9208, Bangladesh. 


\section{Publisher's Note}

Springer Nature remains neutral with regard to jurisdictional claims in published maps and institutional affiliations.

Received: 9 June 2016 Accepted: 22 March 2017

Published online: 27 March 2017

\section{Reference}

1. Randhir SD, Sushma D, Rakesh G. Role of free radical in atherosclerosis, diabetes and dyslipidaemia: larger-than-life. Diabetes Metab Res Rev. 2015; 31(2):113-26. doi:10.1002/dmrr.2558.

2. Ahmad NK, Rahmat AK, Mushtaq A, Nadia M. Role of antioxidant in oxidative stress and diabetes mellitus. J Pharmacogn Phytochem. 2015;3(6): 217-20

3. Suhaila M. Functional foods against metabolic syndrome (obesity, diabetes, hypertension and dyslipidemia) and cardiovasular disease. Trends Food Sci Technol. 2014;35(2):114-28. doi:10.1016/j.tifs.2013.11.001.

4. Chikezie PC, Ojiako OA, Nwufo KC. Overview of anti-diabetic medicinal plants: the Nigerian research experience. J Diabetes Metab. 2015;6(6):546. doi:10.4172/2155-6156.1000546.

5. Rawat M, Parmar N. Medicinal plants with antidiabetic potential-a review. American-Eurasian J Agric Environ Sci. 2013;13(1):81-94. doi:10.5829/idosi. aejaes.2013.13.01.1890

6. Dehghan H, Sarrafi Y, Salehi P. Antioxidant and antidiabetic activities of 11 herbal plants from Hyrcania region. Iran J Food Drug Anal. 2016;24(1):17988. doi:10.1016/j.jfda.2015.06.010.

7. Yusuf M, Chowdhury JU, Haque MN, Begum J. Medicinal plants of Bangladesh. Chittagong: Bangladesh Council of Scientific and Industrial Research; 2009.

8. Angels MB, Joan V. Ethnobotany of Montseny biosphere reserve (Catalonia, Iberian peninsula): plants used in veterinary medicine. J Ethnopharmacol. 2007;110(1):130-47. doi:10.1016/j.jep.2006.09.016.

9. Saima R, AZRA K. Isolation and characterization of peptide(s) from Pisumsativumhaving antimicrobial activity against various bacteria. Pak J Bot. 2011:43(6):2971-8

10. Taha KF, Hetta MH, Ali ME, Yassin NZ, ODE G. The pericarp of Pisumsativum L. (Fabaceae) as a biologically active waste product. Planta Med. 2011;77(12): PJ22. doi:10.1055/s-0031-1282629.

11. Ghani A. Medicinal plants of Bangladesh: chemical constituents \& uses. Dhaka: Asiatic Society of Bangladesh; 2003.

12. Rastogi R, Mehrotra BN. Compendium of Indian medicinal plants, vol. 1 New Delhi: Central Drug Research Institute, Lucknow and National Institute of Science Communication; 1990.

13. Rastogi R. Mehrotra B N. Compendium of Indian medicinal plants. Vol. 3 New Delhi: Central Drug Research Institute, Lucknow and National Institute of Science Communication; 1993.

14. Yusuf M, Chowdhury JU, Wahab MA, Begum J. Medicinal plants of Bangladesh. Dhaka: Bangladesh Council of Scientific and Industrial Research; 1994.

15. Ghani A. Practical Phytochemistry. Dhaka: Parash Publishers; 2005.

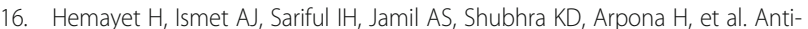
inflammatory and antioxidant activities of ethanolic leaf extract of Brownlowiatersa(L.) Kosterm. Orient Pharm Exp Med. 2013;13:181-9. doi:10. 1007/s13596-013-0109-3

17. Abdulwali A, Jamaludin M, Khalijah A, Jamil AS, Aditya A. Evaluation of antidiabetic and antioxidant properties of Bruceajavanica seed. Sci World J. 2014;1:786130. doi:10.1155/2014/786130.

18. Khirul MI, Nripendra NB, Sanjib S, Hemayet H, Ismet AJ, Tanzir AK, et al Antinociceptive and antioxidant activity of Zanthoxylumbudrunga Wall (Rutaceae) seeds. Sci World J. 2014; doi:10.1155/2014/869537.

19. Azila AK, Azrina A, Amin I, Puziah H, Siti SAG, Badrul HZ, et al. Phenolic composition, antioxidant, anti-wrinkles and tyrosinase inhibitory activities of cocoa pod extract. BMC Complementary Altern Med. 2014;14:381. doi:10. 1186/1472-6882-14-381.

20. Sanjib S, Jamil AS, Himangsu M, Royhan G, Morsaline B, Lutfun N, et al. Bioactivity studies on Musa seminifera lour. Pharmacogn Mag. 2013;9(36): 315-22. doi:10.4103/0973-1296.117827.

21. Naim SMU, Mohammad NA, Shahid-Ud-Daula AFM, Hemayet H, Mahmodul MH, Saifur MR, et al. Phytochemical screening and study of antioxidant and analgesic potentials of ethanolic extract of Stephania japonica Linn. J Med Plants Res. 2014;8(37):1127-33. doi:10.5897/JMPR2014.5443.
22. Latifou L, Abdou MOA, Rafatou AAA, Anatole L, Ambaliou S. Antimicrobial, antioxidant, toxicity and phytochemical assessment of extracts from Acmellauliginosa, a leafy-vegetable consumed in Bénin, West Africa. BMC Complement Altern Med. 2016;16:34. doi:10.1186/s12906-016-1014-3.

23. Any ESSG, Franco ML, Maria SG. Chemical composition and antioxidant/ Antidiabetic potential of Brazilian native fruits and commercial frozen pulps. J Agric Food Chem. 2010;58(8):4666-74. doi:10.1021/jf903875u.

24. Euy-Myoung J, Jaehoon C, Hong L, Yeongju G, Gladstein S, Farzaneh-Far A, et al. Role of mitochondrial oxidative stress in glucose tolerance, insulin resistance, and cardiac diastolic dysfunction. J Am Heart Assoc. 2016;5: e03046. doi:10.1161/JAHA.115.003046.

25. Moein MR, Moein S, Ahmadizadeh S. Radical scavenging and reducing power of Salvia mirzayaniisubfractions. Molecules. 2008;13(11):2804-13. doi: 10.3390/molecules13112804

26. Poonam S, Geetanjali K, Pulkit M. Antidiabetic potential of commonly consumed legumes: a review. Crit Rev Food Sci Nutr. 2014;54(5):655-72. doi: 10.1080/10408398.2011.604141.

27. Gavillán-Suárez J, Aguilar-Perez A, Rivera-Ortiz N, Rodríguez-Tirado K, FigueroaCuilan W, Morales-Santiago $L$, et al. Chemical profile and in vivo hypoglycemic effects of Syzygiumjambos, Costusspeciosus and Tapeinochilosananassae plant extracts used as diabetes adjuvants in Puerto Rico. BMC Complement Altern Med. 2015;15:244. doi:10.1186/s12906-015-0772-7.

28. Dibyendu T. Antioxidant potential and type II diabetes related enzyme inhibition properties of raw and processed legumes in Indian Himalayas. J Appl Pharm Sci. 2013;3(3):13-9. doi:10.7324/JAPS.2013.30303.

29. Zia-Ul-Haq M, Amarowicz R, Ahmad S, Riaz M. Antioxidant potential of some pea (Pisumsativum L.) cultivars commonly consumed in Pakistan. Oxid Commun. 2013:36(4):1046-57.

30. Rajnish G, Anil KS, Mahabeer PD, Sharma MC, Radhey SG. Antidiabetic and antioxidant potential of $\beta$-sitosterol in streptozotocin-induced experimental hyperglycemia. J Diabetes. 2011;3(1):29-37. doi:10.1111/j.1753-0407.2010.00107.x.

31. Sujatha S, Anand S, Sangeetha KN, Shilpa K, Lakshmi J, Balakrishnan A, et al. Biological evaluation of (3b)-STIGMAST-5-EN-3-OL as potent anti-diabetic agent in regulating glucose transport using in vitro model. Int J Diabetes Mellitus. 2010;2(2):101-9. doi:10.1016/j.jjdm.2009.12.013.

32. Palanisamy M, Ganesan K, Murugan R. Antibiabetic efficacy of ellagic acid in streptozotocin induced diabetes mellitus in albino wistar rats. Asian J Pharm Clin Res. 2011:4(3):124-8.

33. Fatima N, Hafizur MR, Abdul H, Shakil A, Maliha N, Nurul K. Ellagic acid in Emblica officinalis exerts antidiabetic activity through the action on $\beta$-cells of pancreas. Eur J Nutr. 2015; doi:10.1007/s00394-015-1103-y.

34. Rana MI, Ali MEH, Dalia OS, El Moataz BEN, Abd ERO. El-Shabrawy, Seham S EH. HPLC-DAD-MS/MS profiling of phenolics from Securigerasecuridaca flowers and its anti-hyperglycemic and anti-hyperlipidemic activities. Rev Bras. 2015;25(2):134-41. doi:10.1016/j.bjp.2015.02.008.

35. Ortiz-Andrade RR, Sánchez-Salgado JC, Navarrete-Vázquez G, Webster SP, Binnie M, García-Jiménez S, et al. Antidiabetic and toxicological evaluations of naringenin in normoglycaemic and NIDDM rat models and its implications on extra-pancreatic glucose regulation. Diabetes Obes Metab. 2008;10(11):1097-104. doi:10.1111/j.1463-1326.2008.00869.x.

36. Flávia Almeida S, Julyanne TF, Bruno RA, Tiago SM, Armenio ACAS, Gerly ACB, et al. Antihyperglycemic and hypolipidemic effects of $a, \beta$-amyrin, a triterpenoid mixture from Protium heptaphyllum in mice. Lipids Health Dis. 2012;11:98. doi:10.1186/1476-511X-11-98.

37. Phang $\mathrm{CW}$, Malek SN, Ibrahim H. Antioxidant potential, cytotoxic activity and total phenolic content of Alpiniapahangensis rhizomes. BMC Complement Altern Med. 2013;13:243. doi:10.1186/1472-6882-13-243.

38. Vanessa SG, Thiago CS, Isael AR, Marisi GS, Marcelo AS, Wagner $V$, et al. Isolation and evaluation of the antioxidant activity of phenolic constituents of the Garcinia brasiliensis epicarp. Food Chem. 2012;132(3):1230-5. doi:10. 1016/j.foodchem.2011.10.110

39. Kilic I, Yeșiloğlu Y, Bayrak Y. Spectroscopic studies on the antioxidant activity of ellagic acid. Spectrochim Acta A Mol Biomol Spectrosc. 2014;130:447-52. doi:10.1016/j.saa.2014.04.052

40. Melguizo-Melguizo D, Diaz-de-Cerioa E, Quirantes-Pinéb R, Švarc-Gajićc J, Segura-Carreteroa A. The potential of Artemisia vulgaris leaves as a source of antioxidant phenolic compounds. J Funct Foods. 2014;10:192-200. doi:10.1016/j.jff.2014.05.019.

41. Albert AB, Savarimuthu I, Gabriel MP, Khalid SN. Chemopreventive potential of $\beta$-Sitosterol in experimental colon cancer model - an in vitro and in vivo study. BMC Complement Altern Med. 2010;10:24. doi:10.1186/1472-6882-10-24. 
42. Tammy J, Jnanabrata B, George M, Quincy T, Agra MF, Reinaldo A. Flavonoids from the root-bark of Diocleagrandiflora. Phytochemistry. 1999; 52(4):723-30. doi:10.1016/50031-9422(99)00314-3.

43. Athar A, Elikana MG, Radhika S. Bioactive chemical constituents of Caesalpiniabonduc (Fabaceae). Phytochem Lett. 2009;2(3):106-9. doi:10.1016/j.phytol.2009.02.002.

44. Amen YM, Marzouk AM, Zaghloul MG, Afifi MS. Bioactive compounds from Tipuanatipu growing in Egypt. J Am Sci. 2013;9(10):334-9.

45. Maruthupandian A, Mohan VR. GC-MS analysis of some bioactive constituents of Pterocarpusmarsupium Roxb. Int J Chem Tech Res. 2011;3(3): 1652-7.

46. Manju LZ, Prasanna LZ, Ashish KD, Aslam MA. Clitoriaternatea(aparajita): a review of the antioxidant, antidiabetic and hepatoprotective potentials. Int J Pharm Biol Sci. 2013;3(1):203-13.

47. Maurice DA, Lyndy JMG, Sebastian G, Roukayatou M, Pierre T, Michael S, et al. Antimicrobial activity and cytotoxicity of the ethanol extract, fractions and eight compounds isolated from Eriosemarobustum (Fabaceae). BMC Complementary Altern Med. 2013;13:289. doi:10.1186/1472-6882-13-289.

48. Leela V, Saraswathy A. Isolation and characterization of phytoconstituents from Acacia leucophloea flowers (Roxb) wild. Int Res J Pharm. 2013;4(9):107-9.

Submit your next manuscript to BioMed Central and we will help you at every step:

- We accept pre-submission inquiries

- Our selector tool helps you to find the most relevant journal

- We provide round the clock customer support

- Convenient online submission

- Thorough peer review

- Inclusion in PubMed and all major indexing services

- Maximum visibility for your research

Submit your manuscript at www.biomedcentral.com/submit
Biomed Central 